\title{
Digital Literacy in the Perspective of the Philosophy of Science Through the Media Literature
}

\author{
Muhammad Alan Ad'ha Firdaus', Stephanie Margaretha Waskito², Moses Glorino \\ Rumambo Pandin ${ }^{3}$ \\ ${ }^{1,2}$ Filsafat Ilmu, Universitas Airlangga \\ J1. Airlangga No.4 - 6, Airlangga, Kec. Gubeng, Kota SBY, Jawa Timur 60115 \\ ${ }^{1}$ muhammad.alan.adha-2020@fib.unair.ac.id \\ ${ }^{2}$ stephanie.margaretha.waskito-2020@fib.unair.ac.id \\ ${ }^{3}$ moses.glorino@fib.unair.ac.id
}

Corresponding Author E-mail: moses.glorino@ fib.unair.ac.id

Jl. Dharmawangsa Dalam, Airlangga, Gubeng, Surabaya, Jawa Timur 60286

(031) 5035676

\begin{abstract}
The scientific article contains a survey on digital media literacy of Universitas Airlangga students which was conducted with the aim of knowing the understanding of students from all universities in Indonesia regarding digital media, and to find out how high the individual level of competence of students in Indonesia is in digital media literacy, as well as to find out the factors what influences the level of competent individuals regarding digital media literacy. This research was conducted using a descriptive survey method and using descriptive statistical data analysis techniques to analyze the research data. The results of the study revealed that: 1). The understanding of students in Indonesia regarding digital literacy is in the medium category, 2). The competent individual level of Indonesian students in digital media literacy is at the basic level, 3). The factors that influence the level of competent individuals related to digital media literacy are mainly family environmental factors.
\end{abstract}

Keywords: digital media literacy, students, competent individuals

\section{INTRODUCTION}

\section{Digital Media Literacy}

Indonesia is currently experiencing rapid development in technology that demands all aspects of life to move quickly, including in the field of literacy. Literacy no longer refers to physical transcripts but digital forms. According to Paul Gilster in his book entitled Digital Literacy (1997), digital literacy is defined as the ability to understand and use information in various forms from a very wide variety of sources that are accessed through computer devices. (https://gln.kemdikbud.go.id/glnsite/wpcontent/uploads/2017/10/literasi-DIGITAL.pdf).

According to Bawsen, digital literacy actually places more emphasis on computer literacy and information literacy. Where computer literacy itself has existed since the 
1980s and only spread widely in the 1990s. This is where the development of digital literacy becomes more accessible and more widespread. According to Bawden, digital literacy is a technical skill in accessing, understanding, compiling, and disseminating information. Where in the millennial era like now, this kind of thing is very familiar. not only familiar but has become a necessity in everyday life.

According to Mayes and Fowler, there is a principle to develop digital literacy gradually. The first is digital skills, which emphasizes skills, methods, behaviors, and concepts. In addition, there is the use of numbers themselves, with a focus on implementing digital capabilities. Lastly, digital transformation certainly requires innovation and creativity which are important elements of digitization.

Many students in the era of cyber society like to access information via the internet, ranging from games to social media, which can facilitate friendship in life. According to the author, student life today can be compared as incomplete when carrying sophisticated digital tools, such as chicken soup without chicken, digital media is now increasingly becoming a primary need for students, students tend to have a high dependence on looking for existing websites or news. on the Internet.

Students can already be categorized in the category of addicts (addiction) in using digital media in everyday life. The teaching and learning process also uses a browser that we know as Google and is often used in solving answers. As a result, students rarely look for answers in books. Lecturers often give assignments in the form of scientific articles, papers, and papers with various themes. However, students will choose to search for it on Google and when they find the right one, they will just click, copy and paste.

\section{Wattpad}

Wattpad is a platform or application from Toronto Canada where this tool is used by users to read or submit and also write works in the form of articles, short stories, novels, poems, or the like. Wattpad was published in 2006 by Allen Lau and Ivan Yuen. Most users come from the United States. Then along with the development and the number of users has now expanded rapidly in Indonesia.

This media has many advantages including being easy to access, can be taken anywhere, flexible, namely by installing it via the AppStore if the user (apple), the play store if the user (android), the Wattpad application can also be opened via a PC or what we usually call a computer, Tablets and all Gadgets. This application is free but to access it we need to use the internet on your gadget, the Wattpad application also has a feature where later the book is read offline without having to connect or be connected to the internet. And 
I think Wattpad is a very interesting application because it can make those of us who initially don't like reading books, because humans don't like complicated things, and this Wattpad might be a human solution wherever and whenever we can use it wisely.

As technology develops, various conveniences in living daily life are being offered in digital media, such as the internet. Students who have the opportunity to undergo higher education, have advantages and benefits that are much higher than people who experience some disadvantages so that they cannot pursue a proper education. Therefore, students are expected to have excellent individual competence. With the presence of the internet that helps the development of digital media, students are expected to be able to process and utilize it optimally.

However, the relationship between digital media and students also has a negative impact. The Internet provides a lot of information, but not necessarily true. If the reader directly swallows the information obtained, it will be bad for the community.

Thus, the Indonesian people, especially teenagers, are expected to keep pace with the times so that information is not left behind. This fact is of course very worrying and needs to be followed up, considering that reading culture is very closely related to the continuity of the next generation that will develop. If interest in reading is high, so will the quality of higher education in order to achieve quality human resources.

Therefore, to overcome this problem, teenagers must have digital literacy skills, one of which is through the online reading application media, namely Wattpad. Wattpad as a reading application that has mushroomed among teenagers, has a significant contribution to the development of digital literacy and can channel talent in the field of writing. We will publish this scientific paper on online article platforms, namely www.preprints.com and www.f1000research.com with the benefit of bringing Indonesian youth more interested in digital literacy.

1. The following is related to the formulation of the problem;

2. Why do students in Indonesia use digital media a lot for literacy?

3. What makes students individual competent in digital media literacy nowadays?

4. What factors influence an individual's level of competence regarding digital media literacy?

This study uses a questionnaire method which will be distributed to students of the Faculty of Cultural Sciences, Airlangga University. In answering some of the problem formulations, the questions and statements we make are in three parts, namely a statement 
regarding the Understanding of Digital Media Functions, a statement about the Level of Media Literacy (Individual Competence) consisting of Use Skills, Critical Understanding, Communicative Abilities, the next is a statement regarding Influence Factors Digital Media Literacy Level.

\section{METHOD}

According to Hasibuan, Zainal A. (2007), the literature review contains descriptions of theories, findings, and other research materials obtained from reference materials to be used as the basis for research activities. The description in question is directed at developing a clear framework of thinking in solving a problem that has been described previously in the problem formulation. Literature Review contains reviews, summaries, and the author's thoughts on several library sources (can be articles, books, slides, information from the internet, etc.) about the topics discussed and is usually placed at the beginning of the chapter. The results will be examined and sorted as a comparison to be studied. The research we use uses a survey method. The approach we take in this research, we use a descriptive qualitative approach that aims to provide a systematic and accurate study, the truth, and also events that have to do with digital literacy within the scope of Airlangga University. Qualitative descriptive method is a research method based on the philosophy of postpositivism which is used to examine the condition of natural objects (as opposed to experiments) where the researcher is the key instrument, the technique of collecting data is done by triangulation (combined), the data analysis is inductive/qualitative, and the results This qualitative research emphasizes meaning rather than generalization (Sugiyono 2016:9).

\section{Type of Research Data}

Data is information or information that can be and is used, including everything that has to do with the purpose of the research. According to statisticians, purposive sampling is more appropriate to be used by researchers if a study requires special criteria so that the samples taken later in accordance with the research objectives can solve research problems and can provide more representative values, Sugiyono (2010). we divide it into 2 types, namely primary data and secondary data. Primary data is data that we get from the main source or original source that contains the information or data we need. As a qualitative researcher, in this case, primary data is used as the main data, where the substance of the primary data, in this case, is in the form of words and actions, namely data and actions from predetermined research subjects. Data was obtained from Airlangga University students who are active in the $2021-2022$ academic year by using a questionnaire or 
questionnaire and interviews as a complement if time permits. Secondary data is data that contains other data or additional data obtained and used as a complement to primary data or primary data, secondary data used in this study obtained from written sources can be divided into sources of scientific books and magazines, archival sources, and personal sources. documentation. Secondary data is data that does not directly provide data to data collectors. Secondary data in the form of books and news from the internet to journals that have been published.

\section{Sampling and Population Data}

The population is a collection of all members of the object of research and fulfills certain criteria that have been determined in research. Research involving the population as the object of research is called a census, then if the sample is certain students from each department in the Faculty of Cultural Sciences, which involves the sample as the object of research. Respondents who will be sampled in this study are all undergraduate students of Universitas Airlangga from the Faculty of Cultural Sciences, namely English Language and Literature, History, Japanese Studies, and Indonesian Language and Literature. The sampling technique was carried out by means of quota sampling and incidental sampling, then the data was collected using a questionnaire or questionnaire. The characteristic of this research is that the data is collected from a large number of respondents using a questionnaire.

In the research process, we used a simple random sampling technique. The sample in this study were Airlangga University students, especially the Faculty of Cultural Sciences community who were active in the odd semester of the 2020-2021 academic year. Furthermore, Airlangga University students, especially the Cultural Sciences community who were active in the odd semester of the 2020-2021 academic year, would be selected by stratified random sampling. Stratified random is done by first grouping Airlangga University students based on the study program and then it will be strengthened by interviewing respondents to find accurate results. This method is used so that the selected sample is more representative. The number of active students was $2216,2.5$ percent was taken as a sample, namely 59 students. A sampling of 2.5 percent was carried out with consideration of limited funds and research time. However, the 2.5 percent sample did not reduce the results of the study.

\section{Data Collection Technique:}

\section{Observation (observation)}


This study uses the method of direct observation to the research location, intended to determine the objectivity of the existing facts about the state and condition of the object to be studied. Observations were made directly rather than the object that the author studied, this observation also has a specific purpose, namely to find out directly the research subject through social media by means of the internet and also interviews.

The type of observation in this study is non-participant observation. According to Riyanto (2010: 98-100), he expressed the opinion that "Observation is said to be nonparticipant if the observer does not take part in the observer's life."

\section{Questionnaire and Interview}

according to Sugiyono (2014: 230), a questionnaire is a data collection technique by which researchers provide a list of questions or written statements to be answered by respondents. In this study, the authors distributed questionnaires directly to the people of the Faculty of Cultural Sciences. This study uses statements and questions regarding digital literacy, especially the Wattpad application as a questionnaire tool. then it will be strengthened by interviewing respondents to find accurate results.

\section{Data Analysis Technique}

The first step in analyzing research data is to create a frequency table. This frequency table was created for all research-related and self-leveled. although the tables are not included in many research reports. According to Sugiyono (2016; 335), qualitative data analysis is inductive in nature, namely an analysis based on the data obtained, then a certain relationship is developed or becomes a hypothesis. These tables will later become a basic material that serves for further analysis, in addition to research, this can also be made as a record of the research data. These frequency tables have various functions, including checking whether the respondent is consistent with the answers to other questions, second, getting a description of the characteristics or characteristics of the respondent on the basis of the analysis of one particular variable, studying the distribution of research variables, determining the best classification for cross-tabulation. (Singarimbun, 2011; 264) there is also the purpose of analyzing one variable data, namely showing the characteristics of the sample in the study, this analysis is considered by many people as a means of enlightening population characteristics. When finished, the author will arrange a table, the author needs to provide an interpretation, in another sense by (L.R GAY) said that quantitative interpretation is to connect the results of the analysis with the theories in the previous chapter so that the most importantly final results are easy for readers to understand. 


\section{RESEARCH RESULT}

Research on the level of digital media literacy of students in Indonesia uses a survey method with the main review of individual competence which is divided into several categories, namely use skills, critical understanding, and communicative abilities in understanding the function of digital media and realizing its influence.

This research was conducted at Airlangga University in the city of Surabaya with a time of approximately two months with a focus on students in Indonesia. Respondents are concentrated in students who have been active in operating gadgets for the last two months or so. Respondents were selected using a two-step sampling technique. In the first stage, purposive selection of students will be used as samples. The community in this study comes from students in Indonesia who are active. Furthermore, stratified random sampling is the next stage to re-select the students to be selected.

Table 1. Data on the Number of Students of Airlangga University Faculty of Cultural Sciences 2020-2021

\begin{tabular}{|l|l|l|l|}
\hline \multicolumn{1}{|c|}{ Major } & \multicolumn{1}{|c|}{ Student } & \multicolumn{1}{c|}{ Sample } \\
\hline 1. & $\begin{array}{l}\text { English language and } \\
\text { literature department }\end{array}$ & 845 & 20 \\
\hline 2. & $\begin{array}{l}\text { Indonesian language and } \\
\text { literature department }\end{array}$ & 644 & 19 \\
\hline 3. & Japanese Studies & 276 & 12 \\
\hline 4. & History Science & 451 & 8 \\
\hline & Total & 2216 & 59 \\
\hline
\end{tabular}

To measure the level of literacy ability using digital media or individual competence, it is divided into three categories, namely:

1. Use Skills is an ability that is done by accessing and operating the media. This skill uses several methods that cover several criteria, namely: the ability to use media 
(Media Skills), the ability to use media continuously or actively (balanced and actively use media), the ability to use and utilize the media highly.

2. Critical understanding is the ability to analyze and evaluate media content comprehensively. Criteria for critical understanding include a. Ability to understand media content and function (understand media content and function) b. Knowledge of media and media regulation (knowledge of media and media regulation) c. User behavior in using media (user behavior).

Critical understanding grids, specifically on the ability to understand media functions, including:

1. The level of trustworthiness of information sources between the internet and mass media (television, radio, and print newspapers);

2. Can distinguish sites that contain good things and not.

3. Understanding of government regulations;

4. Ability to maintain privacy

5. Cross check news sources

1. Communicative ability is the ability to communicate and contribute through the media. Communicative ability includes the ability which can build a social relationship and also contribute to society through the media. In addition, communicative skills include the ability to build and produce media content. Critical understanding grids, especially in communication skills through media, include:

1. Status updates on social media;

2. Criticize through social media;

3. Update news from the internet Statement about.

\section{Factors Influencing the Level of Digital Media Literacy Include:}

1. The introduction of the internet for the first time;

2. The person who first introduced the internet;

3. Regulation of parents' internet use;

4. Internet access time;

5. Frequently accessed sites.

After getting the value or score of the questionnaire, the weight of each component of the assessment of understanding the digital media function, the level of media literacy 
(use skills, critical understanding, and communicative abilities), the factor influencing the level of digital media literacy, the next step is to analyze the results of the questionnaire calculations and combine them with the respective weights. each component. The results of these calculations will then determine the level of media literacy ability and answer questions in the formulation of research problems. The total score for each point is explained as follows:

Statement on Understanding Digital Media Functions with the highest total score of 70 and the lowest total score of 25 ;

> Statement on Media Literacy Level (Individual Competence):

a. Use Skills highest score 160 and lowest score 15;

b. The highest Critical Understanding score is 140 and the lowest score is 12;

c. The highest Communicative Abilities score is 65 and the lowest score is 35;

The highest total score is 365 and the lowest total score is 62 .

\section{DISCUSSION}

Statement on Factors Influence of Digital Media Literacy Level with the highest total score of 95 and the lowest total score of 19; In this case, the level of media literacy ability is divided into three categories, namely basic, medium, and advanced.

1. Basic: The ability to operate the media is not very high, the ability to analyze media content is not too good, and the ability to communicate through media is limited. The value for this basic ability level is in the score with a value range of 70-116.

2. Medium: The ability to operate the media is quite high, the ability to analyze and evaluate media content is quite good, and is active in producing media content and participating socially. The value for this medium level of ability is in the score with a value range of $117-232$.

3. Advanced: The ability to operate the media is very high, has high knowledge so that it is able to analyze media content in-depth, and is able to communicate actively through the media. The value for this advanced ability level is in the score with a value range of 233-350.

\section{Understanding of Airlangga University Students, Faculty of Cultural Sciences Regarding the Functions of Digital Media.}

The data obtained from the respondents are as follows, from the total sample of 59 people, 5 people have scores ranging from 51-75, and 35 have scores ranging from 26-50, while 19 people have scored $0-25$. These results will be analyzed further in the discussion. the following : 
The scoring results show the results in percentage as follows:

1) Respondents as many as 59 as many as 9 percent are in the category of high media function understanding.

2) Respondents as many as 59 as many as 74 percent are in the category of understanding medium media functions.

3) Respondents of 59 as many as 17 percent are in the category of low understanding of media functions.

From the scoring results, it can be interpreted that the majority of respondents have an understanding level in the medium category, whereas respondents who have smartphones on average do not understand the functions of digital media in depth. The majority of students who already have smartphones use or subscribe to internet data packages. The use of this internet access is mostly for visiting sites that provide definitions or meanings of a sentence as well as sites containing lecture assignments that can be downloaded for free. Students have very high access to smartphones and have high confidence when they have the latest gadgets.

Individual Competence Level of Airlangga University Students, Faculty of Cultural Sciences in Digital Media Literacy

The level of individual competence is measured in three domains as follows: Use Skills The data obtained from the respondents are as follows, from the total sample of 59 people, 14 people have scores ranging from $98-145$, and 35 have scores ranging from 49-9, while 10 people have score $0-48$ these results will be analyzed further in the following discussion:

The scoring results show the following results:

1) Respondents of 59 as many as 11 percent are in the advanced category of mastering the use of digital media.

2) Respondents of 59 as many as 80 percent are in the medium category of mastering the use of digital media.

3) Respondents of 59 as many as 9 percent are in the basic category of mastering the use of digital media.

From the scoring results, it can be interpreted that the majority of students have the ability to access and operate media in the medium category. This research has shown how each individual has been able to use the media for different purposes. The majority of 
students can use the internet in the sense that they are able to use the internet but have not been able to sort out the contents of the site.

Medium Category: The ability to operate the media is quite high, the ability to analyze and evaluate media content is quite good, and is active in producing media content and participating socially.

The data obtained from the respondents are as follows from the total sample, namely 59 people, 17 people have scores ranging from 87 to 130, and 22 have scores ranging from 44 to 86 , while 20 people have scores from 0 to 43 . These results will be analyzed further in the discussion. the following :

The scoring results show the following results:

1) Respondents of 59 as many as 5 percent are in the advanced category of being able to provide criticism to the media.

2) Respondents of 59 as many as 10 percent are in the medium category with the ability to provide criticism to the media.

3) Respondents of 59 as many as 85 percent are in the basic category of being able to give criticism to the media.

From the scoring results, it can be interpreted that the majority of students in terms of ability to analyze and evaluate media content comprehensively are in the Basic category. The Basic category means that the ability to operate media is not too high, the ability to analyze media content is not too good, and the ability to communicate through media is limited.

\section{Communicative Abilities}

The data obtained from the respondents are as follows, from the total sample of 59 people, 9 people have scores ranging from 51-55, and 10 have scores ranging from 26-50, while 40 people have scored $0-25$. These results will be analyzed further in the discussion. the following: The scoring results show the following results:

1) Respondents totaling 59 as many as 3 percent are in the advanced category of the ability to use digital media as a means of communication and participation

2) Respondents of 59 as many as 10 percent are in the medium category of ability to use digital media as a means of communication and participation.

3) Respondents of 59 as many as 87 percent are in the basic category of ability to use digital media as a means of communication and participation.

From the scoring results, it can be interpreted that the majority of students in terms of communication skills and participation through the media are in the basic category. The 
basic category means that the ability to operate media is not too high, the ability to analyze media content is not too good, and the ability to communicate through media is limited. The total score of individual competence of Airlangga University students, Faculty of Cultural Sciences which consists of three assessment items is in the basic category.

After conducting research related to understanding the function of digital media, the level of media literacy (Individual Competence), and the factors that influence the level of digital media literacy, therefore the researcher tries to examine more deeply the research results so that the research questions presented in the problem formulation can be answered. From the results of the research above, it can be interpreted that most of the respondents have a level of understanding that is included in the medium category, i.e. most of the respondents who have gadgets or smartphones mostly do not understand the functions of digital media in depth.

The majority of students who already have smartphones use or subscribe to internet data packages. The use of this internet access is mostly for visiting sites that provide definitions or meanings of a sentence as well as sites containing lecture assignments that can be downloaded for free. Students have very high access to Smartphones and have high confidence when they have the latest gadgets. From the scoring results, it can be interpreted that the majority of students have the ability to access and operate media in the medium category.

This research has shown how each individual has been able to use the media for different purposes. The majority of students can use the internet in the sense that they are able to use the internet but have not been able to sort out the contents of the site. Medium Category: The ability to operate the media is quite high, the ability to analyze and evaluate media content is quite good, and is active in producing media content and participating socially. The problems in this research have been stated in the research results section above. The solutions to these problems are described as follows: the first and foremost is to raise or raise awareness from students about the impact of digital media.

The impact in this case is all positive and negative things contained in messages in digital media. Positive impact if the information received contains values, norms that are recognized in the community and increase knowledge. The negative impact is if it contains elements that are not educational, smells of pornography, and SARA (Ethnicity, Religion, Race, and Inter-Group).

\section{CONCLUSION}


Based on the results of the research and the discussion in the previous chapter, this conclusion is the answer to the formulation of the problem as follows:

1. The understanding of students in Indonesia regarding digital media is in the moderate category, which means that most students who have sophisticated electronic goods such as gadgets or smartphones do not fully understand the use of gadgets properly, correctly, and optimally.

2. The level of individual competence of students in Indonesia regarding digital media literacy is in the basic category, with the following description: use skills in the medium category, critical understanding in the basic category, communicative abilities in the basic category. The basic category is the ability to utilize the media is not too high, the related ability to analyze content in the media is not too good, and the ability to communicate through the media is very limited.

3. The most dominant factor that influences the level of individual competence in digital media literacy is the family environment. The introduction of digital media at a very early stage requires the role of parents because parents have a very big influence.

The results of the research above have only been tested for two months and will change over time. However, we will continue to conduct further research related to digital literacy from the perspective of the philosophy of science and to find out for sure about the factors related to digital media literacy. For further researchers, researchers suggest further and in-depth research on digital media literacy from the perspective of the philosophy of science. So that it can be seen more critically about the aims and objectives of digital media literacy, and hopefully this research can be a reference material for other researchers who want to research and know more about digital media literacy. Research limitations or limitations are potential weaknesses in research and are certainly beyond the control of researchers. Researchers find limitations in almost everything we do in the digital media literacy research process. However, we still try our best and provide optimal results in this study.

\section{REFERENCES}

Adnjani, Made Dwi. "Strategi Sinergitas Wartawan dan Akademisi dalam Gerakan Sosial Literasi Digital di Jawa Tengah." SOSFILKOM: Jurnal Sosial, Filsafat Dan Komunikasi 14.01 (2020): 47-55.

Agustin, Intan Rokhmatika Dwi. Aktivitas Organisasi Profesi Jurnalis dalam Program Literasi Digital (Studi Pada Aliansi Jurnalis Independen Malang Tentang Belajar Cek Fakta). Diss. University of Muhammadiyah Malang, 2019. 
Anggrasari, L. A. (2020). Penerapan e-learning untuk meningkatkan kemampuan literasi digital di era new normal. Premiere Educandum: Jurnal Pendidikan Dasar dan Pembelajaran , 10 No. 2, 249-254. From scholar.archive.org

Atep Sujana, D. R. (2019). Literasi digital abad 21 bagi mahasiswa PGSD: apa, mengapa, dan bagaimana. Current Research in Education: Conference Series Journal, 1, 2-6.

Benaziria, Benaziria. "Pengembangkan Literasi Digital pada Warga Negara Muda dalam Pembelajaran PPKn melalui Model VCT." Jupiis: Jurnal Pendidikan Ilmu-Ilmu Sosial 10.1 (2018): 11-20.

Dakir, Zubaidi, A., \& Hasanah, N. S. (2021). Membangun Inklusifitas Beragama Melalui Literasi Digital di Ma’had Aly. Jurnal Islam Nusantara, 4 No. 02, 258- 269. From jurnalnu.com

Dharma, G. S. (2020). Tingkat Literasi Digital Kalangan Pemilih Pemula Di Kota Surabaya. Thesis (Skripsi), III-1, III-9. From http://repository.unair.ac.id/id/eprint/94991

Dinata, K. B. (2021). Analisis Kemampuan Literasi Digital Mahasiswa. Edukasi: Jurnal Pendidikan, 19, No 1, 105-119. From journal.ikippgriptk.ac.id

Fauzi, Hilman. Pemanfaatan Teknologi Gadget Terhadap Pengaruh Sosial Emosi AUD dalam Konsep Pembelajaran Literasi digital. Pedagogi: Jurnal Ilmu Pendidikan 20.1 (2020): 50-53.

Fitriana, S., Rinandiyana, L. R., \& Kurniawan, D. (2019). Pengaruh Integrasi Teknologi dan Literasi Digital Terhadap Keunggulan Bersaing Cinema 21. Jurnal Ekonomi Manajemen, 5 No. 1, 35-40. From http://jurnal.unsil.ac.id/

Ginanjar, Asep, et al. "Implementasi Literasi Digital dalam Proses Pembelajaran IPS di SMP Al-Azhar 29 Semarang." Harmony: Jurnal Pembelajaran IPS dan PKN 4.2 (2019): 99-105.

Hamid, Solihin Ichas, Fauzi Abdillah, and Tuti Istianti. "Mengurai Konstelasi Filosofis Pancasila Melalui Literasi Budaya Kewarganegaraan Dan Literasi Digital Kewarganegaraan." Prosiding Seminar Pendidikan Nasional. Bandung: UPI. 2018.

Hanik, E. U. (2020). Self directed learning berbasis literasi digital pada masa pandemi covid-19 di madrasah ibtidaiyah. ELEMENTARY: Islamic Teacher Journal, 8(1), 183. From scholar.archive.org

Harefa, Hilda Syaf'aini, Shinta Nofita Sari, and Niscaya Hia. "Pengaruh Literasi Digital Terhadap Tingkat Pengetahuan Tentang Hoax Pada Mahasiswa Fakultas Ekonomi dan Ilmu Sosial Universitas Sari Mutiara Indonesia" Jurnal Teknologi Kesehatan dan Ilmu Sosial (Tekenos) 3.2 (2021): 123-138.

Irhandayaningsih, A. (2020). Pengukuran Literasi Digital Pada Peserta Pembelajaran Daring di Masa Pandemi COVID-19. ANUVA, 4 No. 2, 231-240. From ejournal2.undip.ac.id 
Izni, I. (2019). Kemampuan Literasi Digital Dalam Menilai Berita Hoax Di Media Daring Di Kalangan Mahasiswa Aktivis Universitas Airlangga Surabaya. Thesis (Skripsi), 4-15. From http://repository.unair.ac.id/id/eprint/91619

Mawarni, P., Milama, B., \& Sholihat, R. N. (2021). Persepsi Calon Guru Kimia Mengenai Literasi Digital Sebagai Keterampilan Abad 21. Skripsi, 15 No.2, 2849 - 2863. From https://repository.uinjkt.ac.id/

Mustakim, Mohammad, Shoffan Shoffa, and Achmad Hidayatullah. "Pengembangan perangkat pembelajaran blended learning berbasis schoology untuk meningkatkan literasi digital matematika." JUMLAHKU: Jurnal Matematika Ilmiah STKIP Muhammadiyah Kuningan 5.1 (2019): 88-99.

Nasionalita, Kharisma, and Catur Nugroho. "Indeks Literasi Digital Generasi Milenial di Kabupaten Bandung." Jurnal Ilmu Komunikasi 18.1 (2020): 32-47.

Nur, Mahmudah. "Literasi Digital Keagamaan Aktivis Organisasi Keagamaan di Madrasah Aliyah Negeri (MAN) di Kota Bandung." Jurnal SMART (Studi Masyarakat, Religi, Dan Tradisi) 5.1 (2019): 1-14.

Pratama, W. A., Hartini, S., \& Misbah, M. (2019). Analisis Literasi Digital Siswa Melalui Penerapan E-Learning Berbasis Schoology. Journal of Innovation and Physics Teaching, 6 No.1, 9-13. From ejournal.unsri.ac.id

Priambodo, A. W. (2020). Literasi Digital Dalam Menghadapi Informasi Pandemi Covid19 Pada Mahasiswa Ilmu Informasi Dan Perpustakaan Universitas Airlangga Surabaya. Skripsi, 11-18. From repository.unair.ac.id

Rahmawati, Widira. Pengaruh Terpaan Jurnalisme Data di Portal Media Online Terhadap Literasi Digital pada Mahasiswa (Studi pada Mahasiswa Konsentrasi Jurnalistik Ilmu Komunikasi Universitas Muhammadiyah Malang Angkatan 2015). Diss. University of Muhammadiyah Malang, 2019.

Sahidillah, M. W., \& Miftahurrisqi, P. (2019). Whatsapp sebagai Media Literasi Digital Siswa. Jurnal Varidika, 31 No.1, 52-56. From journals.ums.ac.id

Sari, D. K., Bahri, S., Simbolon, M., Nikat, R. F., \& Dinata, P. A. (2020). Pembelajaran Daring Berbantuan Whatsapp Pada Matakuliah Metodologi Penelitian Pendidikan Fisika. Musamus Journal of Science Education (MJOSE), 3 No.1, 25-30. From ejournal.unmus.ac.id

Sari, Z. A. (2019). Literasi Privasi Pada Media Sosial Instagram di Kalangan Mahasiswa Strata 1 Universitas Airlangga Surabaya. Thesis (Skripsi), 2- 12. From http://repository.unair.ac.id/id/eprint/81339

Setyaningsih, R., Abdullah, Prihantoro, E., \& Hustinawaty. (2019, Januari). Model penguatan literasi digital melalui pemanfaatan E-Learning. Jurnal ASPIKOM, 3 No. 6, 1205-1212.

Sormin, Salman Alparis, Ali Padang Siregar, and Cipto Duwi Priyono. "Konsepsi Literasi Digital Dalam Pembelajaran Sejarah di Era Disruptif." (2019). 
Sulistyowati, Tutik, Nur Hayatin, and Gita Indah Marthasari. "Pelatihan Literasi Digital pada Perempuan Kelompok Binaan Sekolah Ibu Arjosari Malang." Jurnal Dedikasi 16 (2019): 14-18.

Syaifurrohman, Syaifurrohman, and Faiz Albar Nasution. "Optimalisasi Pendidikan Politik melalui Literasi Digital bagi Penyandang Disabilitas dalam Industri 4.0 di Indonesia." Jurnal Komunikasi Pendidikan 5.1 (2021): 68-78. 